\title{
Unmasking of poorly controlled diabetes mellitus by pulmonary nocardiosis
}

\author{
Preet Mukesh Shah, ${ }^{1}$ Indraneel Raut, ${ }^{1}$ Susheel Kumar Bindroo, ${ }^{2}$ Vijay Waman Dhakre ${ }^{3}$
}

'Department of Critical Care, Jaslok Hospital and Research Centre, Mumbai, Maharashtra, India

${ }^{2}$ Department of Respiratory Medicine, Jaslok Hospital and Research Centre, Mumbai, Maharashtra, India ${ }^{3}$ Department of Liver Diseases, HPB surgery and Transplantation, Global institute of Liver Diseases, Mumbai, Maharashtra, India

\section{Correspondence to} Dr. Vijay Waman Dhakre, vddrvijayd@gmail.com

Accepted 26 April 2018

\section{DESCRIPTION}

A 60-year-old Indian woman, known case of hypertension with no other comorbidities, presented with productive cough since 20 days and high-grade fever since 5 days. She also had breathlessness since 10 days which was insidious in onset, was initially exertional and had progressed such that it was now present at rest. There was no history of tuberculosis. Her appetite had been significantly reduced since 20 days prior to presentation.

On examination, she was tachypnoeic with a respiratory rate of $30 / \mathrm{min}$, tachycardic with a pulse rate of $140 / \mathrm{min}$, febrile with a temperature of $101^{\circ} \mathrm{F}$. Her blood pressure was normal. Oxygen saturation was $91 \%$ on room air. Coarse inspiratory crackles could be heard in bilateral infra-axillary and infrascapular areas and the right infraclavicular area.

Chest X-ray showed consolidation in bilateral lower and mid zones and a well-demarcated homogenous opacity in right upper zone (figure 1), suggestive of bronchopneumonia. Her arterial blood gas analysis showed respiratory alkalosis with hypoxaemia. Complete blood count showed leucocytosis (white cell count of $18 * 10^{\wedge} 9 / \mathrm{L}$ ) with neutrophils being $85 \%$. Her leucocytosis and clinical picture suggested systemic inflammatory response syndrome. CT scan of chest showed extensive bilateral lower lobe (figure 2) and right upper lobe (figure 3 ) consolidation.

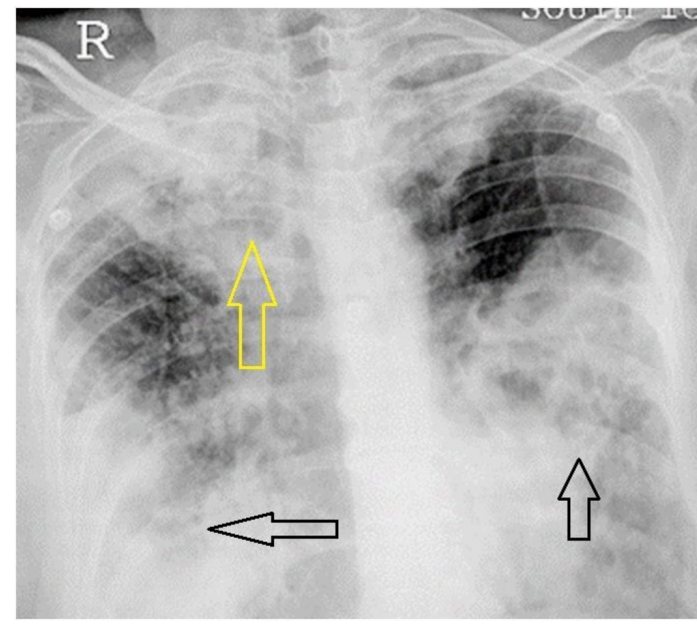

To cite: Shah PM, Raut I, Bindroo SK, et al. BMJ Case Rep Published Online First: [please include Day Month Year]. doi:10.1136/bcr-2018224911
Figure 1 Chest X-ray showing consolidation in bilateral lower and mid zones (black arrow) and a welldemarcated homogenous opacity in right upper zone (yellow arrow).

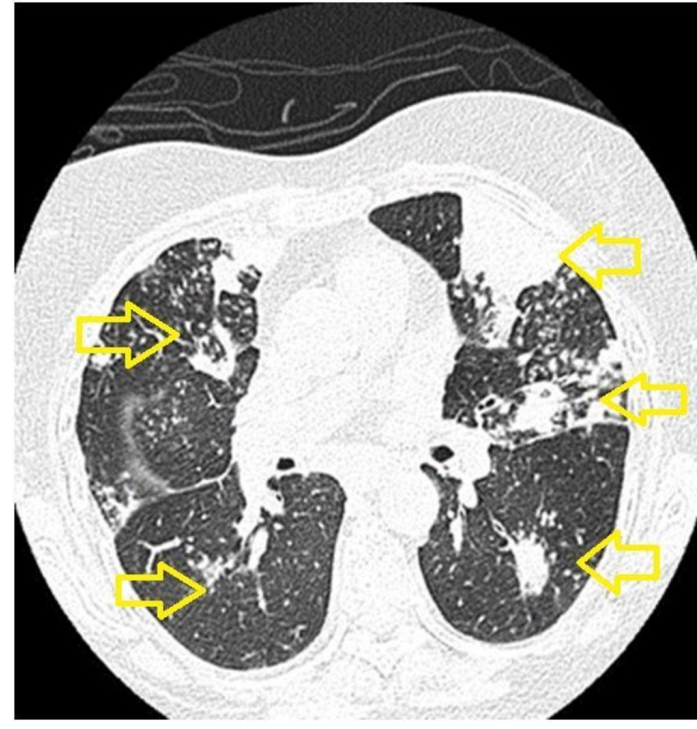

Figure 2 CT scan of chest showing extensive bilateral lower lobe consolidation (yellow arrow).

She was empirically started on intravenous antibiotics. Meanwhile her sputum and blood samples were sent for culture. Her sputum had also been sent for gram and Ziehl-Neelsen staining, tuberculosis culture and Gene Xpert, keeping in mind a likely possibility of pulmonary tuberculosis, considering her clinical and radiological features.

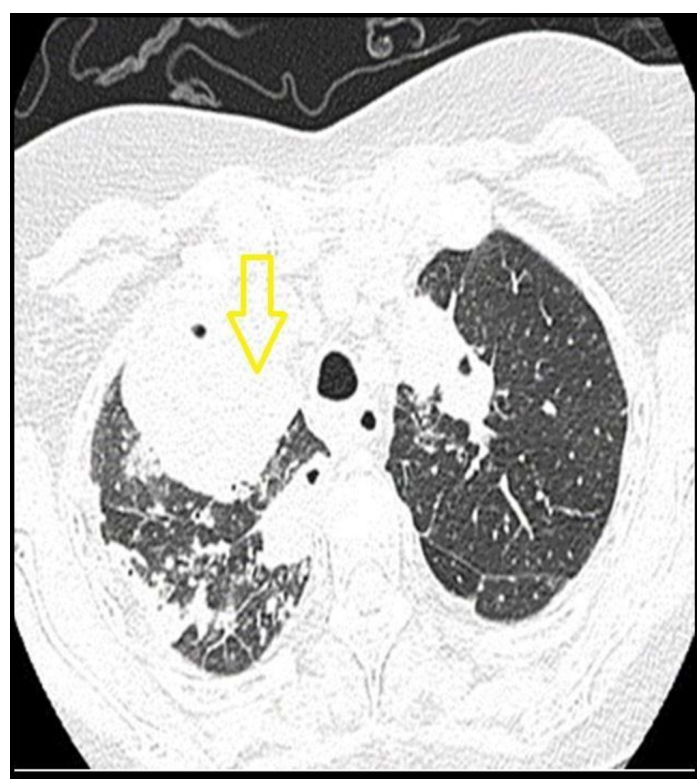

Figure 3 CT scan of chest showing right upper lobe consolidation (yellow arrow). 
Her sputum showed nocardia on gram staining. A diagnosis of pulmonary nocardiosis was made and she was started on cotrimoxazole and ceftriaxone. She had never used steroids. She had done her complete blood count, liver and renal function tests about 3 months back as part of a routine health check-up, which were normal. Her HIV ELISA was negative. Serum levels of immunoglobulins (IgG, IgA, IgE and $\operatorname{IgM}$ ) were normal. Flow cytometry was done to look at counts of B cells, $\mathrm{T}$ cells and natural killer cells which were normal. During her hospitalisation, her random blood glucose levels remained high (ranging from $250 \mathrm{mg} / \mathrm{dL}$ to $300 \mathrm{mg} / \mathrm{dL}$ on an average); thus, her glycosylated haemoglobin was sent which showed a value of $10 \%$, suggesting poorly controlled diabetes mellitus. She had never experienced any symptoms suggestive of diabetes mellitus like polyuria, polydipsia, polyphagia or any weight changes prior to admission. She was started on insulin therapy for better sugar control.

\section{Patient's perspective}

I was quite surprised to find out that I had diabetes as I was not having any features of the condition. I had never ever done any blood tests to look for diabetes either. I shall take better care of my health from now on.

\section{Learning points}

Pulmonary nocardiosis is an important differential of a lower respiratory tract infection occurring in an immunocompromised individual.

- Sputum examination and culture are critical to the diagnosis of pulmonary nocardiosis since its clinical and radiological features closely mimic that of pulmonary tuberculosis, which is a more common condition in India.
Gradually, her fever decreased and leucocytosis subsided. Her oxygen requirement also reduced. Later on, her sputum culture also showed Nocardia asteroides. Ceftriaxone was given for a total period of 2 weeks, whereas oral cotrimoxazole continued for a total period of 6 months.

Nocardiosis is a rare infection occurring in immunocompromised individuals with a prevalence of $1.4 \% .{ }^{1}$ It is usually acquired via the inhalational route. ${ }^{2}$ The clinical features mimic that of pulmonary tuberculosis ${ }^{2}$ which is a more common condition in India. Diabetes mellitus is the underlying immunocompromised state in $27.8 \%$ of patients in India. ${ }^{3}$ The mean age of the affected patients is $54.47 \pm 15.074$ years. $^{3}$

This is an interesting case as an apparently healthy woman was diagnosed with pulmonary nocardiosis and it was only on further evaluation that she was found to be a diabetic which was poorly controlled. This, along with her age as a factor, led to an immunocompromised state which made her susceptible to infection by nocardia.

Contributors PMS wrote up the case history. IR and SKB assisted in the case discussion. VWD acquired the clinical images.

Funding The authors have not declared a specific grant for this research from any funding agency in the public, commercial or not-for-profit sectors.

Competing interests None declared.

Patient consent Next of kin consent obtained.

Provenance and peer review Not commissioned; externally peer reviewed.

(C) BMJ Publishing Group Ltd (unless otherwise stated in the text of the article) 2018. All rights reserved. No commercial use is permitted unless otherwise expressly granted.

\section{REFERENCES}

1 Singh M, Sandhu RS, Randhawa HS, et al. Prevalence of pulmonary nocardiosis in a tuberculosis hospital in Amritsar, Punjab. Indian J Chest Dis Allied Sci 2000;42:325-39.

2 Kandi V. Human nocardia infections: a review of pulmonary nocardiosis. Cureus 2015;7:e304.

3 Singh A, Chhina D, Soni RK, et al. Clinical spectrum and outcome of pulmonary nocardiosis: 5-year experience. Lung India 2016;33:398-403.

Copyright 2018 BMJ Publishing Group. All rights reserved. For permission to reuse any of this content visit http://group.bmj.com/group/rights-licensing/permissions.

BMJ Case Report Fellows may re-use this article for personal use and teaching without any further permission.

Become a Fellow of BMJ Case Reports today and you can:

- Submit as many cases as you like

- Enjoy fast sympathetic peer review and rapid publication of accepted articles

- Access all the published articles

- Re-use any of the published material for personal use and teaching without further permission

For information on Institutional Fellowships contact consortiasales@bmjgroup.com

Visit casereports.bmj.com for more articles like this and to become a Fellow 